\title{
Viral Characteristic of HIV Infected Patients Naïf of Anti-Retroviral Therapy with CD4+ T Lymphocytes Rate Greater than 350 per Microliter of Blood in Lomé Togo
}

\author{
Ihou Nazoba Majesté Wateba, Akouda Akessiwe Patassi, Abago Balaka, Ousséni Tidjani
}

Service de Maladies Infectieuses et de Pneumologie, CHU Sylvanus Olympio, Lomé, Togo.

Email: majeste7@yahoo.fr

Received September $6^{\text {th }}, 2013$; revised October $6^{\text {th }}, 2013$; accepted October $13^{\text {th }}, 2013$

Copyright (C) 2013 Ihou Nazoba Majesté Wateba et al. This is an open access article distributed under the Creative Commons Attribution License, which permits unrestricted use, distribution, and reproduction in any medium, provided the original work is properly cited.

\begin{abstract}
Objective: To evaluate the virological status of ineligible HIV patients for anti-retroviral therapy based on the criterion of CD4+ T lymphocytes rate over than 350/ $\mu$ l of blood. Method: This is a prospective study which was conducted from November 2011 to July 2012 in the tropical and infectious disease department of CHU Sylvanus Olympio of Lomé. All HIV-1 infected patients whose CD4+ T lymphocytes rate was $\geq 350 / \mu l$ of blood were retained. The count of CD4+ T lymphocytes was made by cytometer FACSCalibur ${ }^{\mathbb{B}}$ flow of BD biosciences and the determination of viral load was achieved by NASBA laboratory method of Biomérieux. Results: We have recruited 102 PLWHA aged between 19 and 58 years with a median of 35 years. Biologically, 102 patients had a T-CD4 rate between 355 and 432/ $\mu 1$ of blood. The determination of viral load showed a very high viral replication more than 10,000 copies/ml among all patients and 28 (27.5\%) patients had a viral load $>100,000 \mathrm{copies} / \mathrm{ml}$ of blood. Conclusion: Our results argue for a reconsideration of the criteria for starting antiretroviral therapy in Togo by including virological data if necessary in patients with T-CD4 rate below $500 / \mu 1$ of blood.
\end{abstract}

Keywords: Viral Load; CD4+ T Lymphocytes; Naive Anti-Retroviral Therapy Patients

\section{Introduction}

Twenty-five years after the start of the pandemic of human immunodeficiency virus (HIV) and despite the international mobilization, HIV/AIDS which is a major public health problem in developing countries remains. In Togo, the HIV epidemic has been documented since 1987. Between 1987 and 2005, 20,676 cumulative AIDS cases were officially registered and 110,000 people are living with HIV [1]. The prevalence of HIV infection was successively $5.8 \%$ in $2001,4.1 \%$ in $2003,3.2 \%$ in 2005 and $3 \%$ in 2008 [1]. In 2012, more than 36,000 people have had received antiretroviral therapy. Since 2012, the immunological criteria for starting treatment were reconsidered from $\leq 200 \mathrm{CD} 4+\mathrm{T}$ lymphocytes to $\leq 350 \mathrm{CD} 4+$ $\mathrm{T}$ lymphocytes per $\mu$ l of blood. For higher rates, the initiation of treatment considers the clinical condition of the patient [2-4]. The aim of our study was to evaluate the viral status of patients ineligible for anti-retroviral therapy (CD4+ T lymphocytes rate more than 350 per $\mu$ of blood) according to the national algorithm of Togo.

\section{Method}

This is a prospective study which was done in the tropical and infectious diseases department of CHU Sylvanus Olympio of Lomé in Togo. All patients are HIV-1 infected and naive for anti retroviral treatment. The CD4+ $\mathrm{T}$ lymphocytes rate is between 350 and 500 per $\mu 1$ of blood. The T-CD4 count was performed by the technique of flow cytometry of BD Biosciences FACSCalibur ${ }^{\mathrm{TM}}$. The determination of the viral load was performed by the NASBA method (Nucleid Acid Sequence Based Amplification) with EasyQ BioMerieux equipment.

\section{Results}

Epidemiological data: Two hundred HIV-1 infected patients were included in the study. Seventy-five patients (74.5\%) were female and 27 were male $(25.5 \%)$. The sex ratio $\mathrm{M} / \mathrm{F}$ was 0.34 . The age of patients ranged from 19 to 58 years with a median of 35 years.

Biological data: The rate of CD4+ $\mathrm{T}$ lymphocytes was 
between 355 and 432 per $\mu 1$ of blood and the median value of CD4+ T lymphocyte count was 357 per $\mu$ of blood. The mean viral load of all patients enrolled was 106,136 copies $/ \mathrm{ml}$ and the maximum viral load was $1,000,000$ copies $/ \mathrm{ml}(6 \mathrm{Log} / \mathrm{ml})$ and a minimum value was less than 10,100 copies $/ \mathrm{ml}$. Twenty-eight patients $(27.5 \%)$ had a viral load $>100,000$ copies $/ \mathrm{ml}(5 \mathrm{Log} / \mathrm{ml})$ (Table 1).

\section{Discussion}

Epidemiological data: We observed a female predominance and the sex ratio $\mathrm{M} / \mathrm{F}$ was 0.34 . Our result is similar to the data reported by the national program against HIV in Togo which has related a sex ratio of 0.32 in 2007 [1]. This observation is consistent with the UNAIDS report in 2007 which indicates that $61 \%$ of people infected with HIV in sub-Saharan Africa are women [5] The predominance of women within HIV-1 infected patients in Togo and in the sub-Sahara Africa Region could be explained by early sexual relation among girls, the lack of training and information on the prevention of HIV-AIDS and high-risk behaviours of their partner(s) who provide them incomes and very often, they can not make them use preservative [5]. The age of patients is between 19 and 52 years with a median age of 35 years. This age group is the most active mass of the Togolese population in terms of production of income-generating activities. They also correspond to the sexual active population. Our results are similar to the national HIV program data of Togo in 2007 where more than $74 \%$ of HIV infected patients were aged from 25 to 49 years old.

Biologically, all patients included in this study were not eligible for anti retroviral therapy because of the CD4+ T lymphocyte rate $>350 / \mu 1$ of blood according to the national HIV algorithm in Togo [2]. Indeed, for a long time, Togo as the majority of developing countries had recommended to start the anti retroviral therapy when the CD4+ T lymphocyte rate is $\leq 200 / \mu 1$ of blood. If a better result was demonstrated in many clinical trials with patients who had started the anti retroviral therapy at AIDS stage (CD4+ T lymphocytes rate $<200 / \mu$ of blood) and in many cohort studies of patients with CD4 < 350 per $\mu 1$ of blood, several new arguments, also from cohort studies, argue for an earlier introduction of the first antiretroviral therapy in asymptomatic patients with CD4 rate $>350 / \mu$ l. The benefit is the better viral and im-

Table 1. Distribution of patients according to the viral load.

\begin{tabular}{ccc}
\hline & Viral load & Viral load \\
\hline & $<100.000$ copies $/ \mathrm{ml}$ & $>100.000$ copies $/ \mathrm{ml}$ \\
Total strength & $74(72.5 \%)$ & $28(27.5 \%)$ \\
\hline
\end{tabular}

mune response [6] and the reduction of the morbidity [7] or the improvement of the mortality [8,9]. In addition, HIV infection, regardless of immune deficiency, including levels of CD4+ T lymphocytes $>350 / \mu 1$, increase a risk of morbidity and mortality of cancer, cardiovascular disease and neuro-cognitive disorders which could also justify earlier introduction of antiretroviral therapy $[8,10$, $11]$.

Virologically, $27.5 \%$ of patients had a viral load $>$ $100.000 / \mathrm{ml}$ blood. Indeed, the prognostic value of plasma viral load to initiate anti retroviral treatment is less important than the CD4+ $\mathrm{T}$ lymphocytes rate when the viral load $<100,000$ copies $/ \mathrm{ml}(5 \mathrm{Log} / \mathrm{ml})$. However, several cohort studies have shown that high plasma viral load (especially $>100,000$ copies $/ \mathrm{ml}$ ) is a bad prognostic factor regardless of the CD4 T lymphocytes rate [12-14]. In addition, the quality of the immunological response to antiretroviral therapy decreases with age and is significantly worse after 60 years [15]. The clinical response is also lower in patients over 50 years [16]. A first HAART should help to make undetectable viral load $(<50$ copies ARN-VIH/ml) within 6 months from the beginning of the treatment. However, with some patients, this goal is not reached at that date, and the viral load becomes undetectable after 6 months of treatment. This can be seen especially when the initial viral load $>5$ Log copies $/ \mathrm{ml}$ or in case of low CD4 $\mathrm{T}$ lymphocytes rate.

\section{Conclusion}

Our study has provided sufficient evidence that the relatively high rates of CD4 T lymphocytes $(>350 / \mu 1)$ may be accompanied by a very high viral replication. It is for that reason that today all recommendations argue at early beginning of the anti-retroviral therapy with those HIV infected. However, it is difficult to implement the viral load measurement in developing countries, which appealed to the international generosity to take care of their patients. This study deserves to demonstrate that many remains have to be done to attend universal access care and to achieve the objective 06 of Millennium Development Goals on HIV/AIDS.

\section{REFERENCES}

[1] PNLS-INFO No. 001/2007 PNLS-Togo, 2007, 1-5.

[2] PNLS, "Directives Pour une Prise en Charge Avec les Médicaments Antirétroviraux (ARV) au Togo," 2004, pp 3-9.

[3] PNLS, "Guide National de la Prise en Charge Médiacle du VIH/SIDA: Affections Opportunistes et Traitement par les Antirétroviraux," 2004, p. 104.

[4] OMS, "Recommendation Pour une Approche de Santé Publique: Améliorer L'accès aux Traitements Antirétro- 
viraux dans les Pays à Ressources Limitées,” 2002, pp. 89.

[5] ONUSIDA, "Rapport sur l'Épidémie Mondiale de SIDA," ONUSIDA, Genève, 2006, pp. 3-4.

[6] R. D. Moore and J. C. Keruly, "CD4+ Cell Count 6 Years after Commencement of Highly Active Antiretroviral Therapy in Person with Sustained Virologic Suppression," Clinical Infectious Diseases, Vol. 44, No. 3, 2007, pp. 441-446. http://dx.doi.org/10.1086/510746

[7] J. V. Baker, G. Peng, J. Rapkin, et al., "CD4+ Count and Risk of Non-AIDS Diseases Following Initial Treatment for HIV Infection," AIDS, Vol. 22, No. 7, 2008, pp. 841888. http://dx.doi.org/10.1097/QAD.0b013e3282f7cb76

[8] S. Emery, J. A. Neuhaus, A. N. Phillips, et al., "Major Clinical Outcomes in Antiretroviral Therapy (ART)-Naive Participants and in Those Not Receiving ART at Baseline in the SMART Study," Journal of Infectious Diseases, Vol. 197, No. 8, 2008, pp. 1133-1144. http://dx.doi.org/10.1086/586713

[9] HIV-CAUSAL Collaboration, et al., "The Effect of Combined Antiretroviral Therapy on the Overall Mortality of HIV-Infected Individuals," AIDS, Vol. 24, No. 1, 2010, pp. 123-137. http://dx.doi.org/10.1097/QAD.0b013e3283324283

[10] M. Guiguet, F. Boue, J. Cadranel, J. M. Lang, E. Rosenthal and D. Costagliola, "Effect of Immunodeficiency, HIV Viral Load, and Antiretroviral Therapy on the Risk of Individual Malignancies (FHDH-ANRS CO4): A Prospective Cohort Study," Lancet Oncology, Vol. 10, No. 12, 2009, pp. 1152-1159.

http://dx.doi.org/10.1016/S1470-2045(09)70282-7

[11] C. F. Kelley, C. M. Kitchen, P. W. Hunt, et al., "Incom- plete Peripheral CD4+ Cell Count Restoration in HIV Infected Patients Receiving Long-Term Antiretroviral Treatment," Clinical Infectious Diseases, Vol. 48, No. 6, 2009, pp. 787-794. http://dx.doi.org/10.1086/597093

[12] M. Egger, M. May, G. Chêne, et al., "Prognosis of HIV1-Infected Patients Starting Highly Active Antiretroviral Therapy: A Collaborative Analysis of Prospective Studies," Lancet, Vol. 360, No. 9327, 2002, pp. 119-129. http://dx.doi.org/10.1016/S0140-6736(02)09411-4

[13] J. P. Phair, J. W. Mellors, R. Detels, J. B. Margolick and A. Munoz, "Virologic and Immunologic Values Allowing Safe Deferral of Antiretroviral Therapy," AIDS, Vol. 16, No. 18, 2002, pp. 2455-2459. http://dx.doi.org/10.1097/00002030-200212060-00011

[14] E. Wood, R. S. Hogg, B. Yip, et al., "Higher Baseline Levels of Plasma Human Immunodeficiency Virus Type 1 RNA Are Associated with Increased Mortality after Initiation of Triple-Drug Antiretroviral Therapy," Journal of Infectious Diseases, Vol. 188, No. 10, 2003, pp. 14211425. http://dx.doi.org/10.1086/379201

[15] Collaboration of Observational HIV Epidemiological Research Europe (COHERE) Study Group, et al., "Response to Combination Antiretroviral Therapy: Variation by Age," AIDS, Vol. 22, No. 12, 2008, pp. 1463-1473. http://dx.doi.org/10.1097/QAD.0b013e3282f88d02

[16] A. H. Greenbaum, L. E. Wilson, J. C. Keruly, R. D. Moore and K. A. Gebo, "Effect of Age and HAART Regimen on Clinical Response in an Urban Cohort of HIV-Infected Individuals," AIDS, Vol. 22, No. 17, 2008, pp. 2331-2339. http://dx.doi.org/10.1097/QAD.0b013e32831883f9 